\title{
LEARNING ENGLISH \\ (Ethnographic Studies at SMAN 81 East Jakarta)
}

\author{
Rifari Baron \\ STIKOM PROSIA \\ Jl. Tegalan No.1E, Palmeriam, Matraman Jakarta Timur 13140 \\ (baronshy03@yahoo.com)
}

\begin{abstract}
This research is aimed at analyzing learning and teaching process at Senior High School (SMA) 81 East Jakarta in academic years 2013/2014. The research used a qualitative approach. The research method is ethnographic methods. Tha data were collected through observation, interview, and document analysis. The research analysis used Spradley's terms; domain, taxonomy, and componential analysis, then discovering cultural themes. The research findings showed that 1) the purpose of English learning in SMAN 81 focused on the acquisition of communicative competence; 2) Syllabus was developed by proportional syllabus that emphasized the structure, functions, processes, and experience of language acquisition; 3) Approaches, methods, and techniques used literacy approach based on functional and interactional language theory and constructivism, humanism, behaviorism and cognitive language learning theory; Meanwhile, 4) the evaluation of learning used were written tests, performance tests, portofolios, and product or project.The results of this research showed that the process of learning was effective and students can improve English competence. In addition, the learning process was also well supported by students whom were motivated to learn and the teachers were always eager to continue their innovation as well as a means of learning self-sufficient.
\end{abstract}

\section{Keywords: the English learning, qualitative and ethnography}

\begin{abstract}
ABSTRAK
Penelitian ini bertujuan untuk mengidentifikasi dan menganalisis proses pembelajaran bahasa Inggris di Sekolah Menengah Atas Negeri 81 Jakarta Timur tahun ajaran 2013/2014. Penelitian ini menggunakan pendekatan kualitatif dengan metode etnografi. Pengumpulan data dilakukan melalui pengamatan, wawancara, dan kajian dokumentasi. Analisis data dilakukan berdasarkan model analisis Spradley dengan menggunakan analisis domain, taksonomi, komponensial dan analisis tema budaya.Temuan budaya menunjukan bahwa: 1) bentuk tujuan pembelajaran diarahkan pada penguasaan kompetensi komunikatif; 2) Silabus yang dikembangkan adalah silabus proporsional yang memberikan penekanan seimbang pada struktur, fungsi, proses serta pengalaman memperoleh bahasa; 3) Pendekatan menggunakan pendekatan literasi yang berdasarkan pada teori bahasa fungsional dan interaksional serta teori belajar bahasa konstruktivisme, humanisme, behaviorisme dan kognitivisme; 4) sistem penilaian yang digunakan antara lain; tes tertulis, tes penampilan, portofolio, produk atau proyek.Hasil penelitian tentang proses pembelajaran bahasa Inggris di SMAN 81 menunjukan sangat baik dan efektif dalam meningkatkan kompetensi dalam penguasaan bahasa Inggris karena semua proses pembelajaran yang dilakukan dibuat berdasarkan suatu perencanaan yang matang. Selain itu, proses pembelajaran yang baik tersebut juga di dukung oleh siswa yang termotivasi untuk belajar dan para guru yang senantiasa bersemangat untuk terus melakukan inovasi diri serta sarana pembelajaran yang memadai.
\end{abstract}

\section{Kata Kunci: Pembelajaran Bahasa Inggris, Kualitatif, Etnografi, Pendekatan Literasi}


Bahasa merupakan gejala sosial yang digunakan untuk komunikasi antarmanusia. Sebagai gejala sosial yang komunikatif, kita perlu membedakan penggunaan bahasa berdasarkan tujuan komunikasi. Sebuah tindakan komunikasi secara prinsip megacu kepada perbendaharaan tanda, kode, dan seperangkat aturan yang telah disediakan oleh sistem bahasa. Seperangkat aturan tersebut digunakan di dalam proses komunikasi untuk menghasilkan pesan atau makna tertentu.

Hal yang sama berlaku juga dalam bahasa Inggris sebagai bahasa asing,yang pada masa-masa sekarang ini bahasa Inggris merupakan salah satu bahasa internasional yang digunakan sebagai sarana komunikasi antara bangsa-bangsa di seluruh dunia baik dalam situasi formal maupun informal. Di beberapa negara seperti Amerika, Inggris, dan Australia, berbicara bahasa Inggris sebagai bahasa ibu mereka dan negara lain seperti Singapura dan India, menggunakan bahasa Inggris sebagai bahasa kedua.

Bahasa Inggris memiliki peranan penting dalam setiap aspek kehidupan manusia, seperti bisnis, bidang akademik, pariwisata, dan lain-lain. Karena peranannya yang sangat besar, bahasa Inggris dipelajari di sebagian besar negara sebagai bahasa asing. Negara Indonesia sebagai salah satu negara berkembang juga telah menetapkan kurikulum pendidikan untuk pelajaran bahasa Inggris sebagai bahasa asing. Bahasa Inggris adalah salah satu mata pelajaran yang wajib dan diajarkan pada semua tingkat pendidikan, mulai dari sekolah dasar sampai perguruan tinggi.

Bahasa Inggris sebagai mata pelajaran yang wajib diajarkan di sekolah maupun di perguruan tinggi, maka, pengajarannya pun membutuhkan pengetahuan yang profesional dan keterampilan yang tepat. Kesuksesan dalam proses belajar mengajarnya pun tidak terlepas dari bagaimana seorang guru mengatur dan mengelola kelas serta mengatasi berbagai kendala yang ada di dalam kelas.

Dalam pembelajaran bahasa Inggris di sekolah akan terlibat beberapa komponen, yaitu: siswa, guru, materi, tujuan belajar dan lingkungan belajar bahasa.(Kern, 2000) menyebutkan ada tiga yang harus diperankan oleh siswa maupunguru.Ketiga peran tersebut adalah kegiatan merespon (responding), merevisi (revising) dan merefleksikan (reflecting).

peran siswa dalam (Richards dan Rogers, 1992) menyatakan bahwa pembelajaran mengacu pada pemahaman bahwa semua tindakan yang dilakukan anak berhubungan dengan konteks dan 
aktivitas

belajar

mengajar.

Siswamerupakan objek yang akan dikenai proses pembelajaran dan yang diharapkan mempunyai sikap dan kemampuan yang lebih baik setelah proses belajar mengajar selesai. Sementara guru dalam (Brian Tomlinson, 1998) merupakan kunci utama perubahan pendidikan dan pengembangan sekolah, baik sebagai fasilitator, sebagai informator, maupun sebagai pembimbing. Sejalan dengan hal tersebut(Jeremy Harmer, 1986) mengatakan bahwa ada tiga tahap yang disarankan dalam menilai sebuah materi ajar yang baik buat siswa yaitu: seorang guru harus membuat catatan, guru harus berdiskusi dengan rekan sejawatnya, mendapatkan umpan balik dari siswa setelah siswa diberikan materi ajar dari buku teks yang dipergunakan. Maka materi ajar, dapat dipahami sebagai materi yang harus disampaikan oleh guru kepada para siswa dalam proses pembelajaran. Tujuan belajar merupakan sesuatu yang akan dicapai melalui proses pembelajaran. Lingkungan belajar yakni tempat dimana pembelajaran bahasa itu berlangsung.

Keberhasilan pembelajaran bahasa, juga ditentukan oleh faktor lingkungan. Farhan (2004:5) dalam disertasinya mengemukakan bahwa lingkungan kebahasaan adalah lingkungan bahasa Inggris yang mendukung seperti; lingkungan keluarga, masyarakat dan lingkungan tempat siswa belajar. Siswa yang berasal dari keluarga yang harmonis dan memperhatikan kegiatan belajarnya, berpotensi lebih berhasil dari pada siswa yang berasal dari keluarga yang tidak harmonis dan tidak memperhatikan kegiatan belajarnya. Demikian juga dengan siswa yang tinggal dalam lingkungan masyarakat yang baik, jujur, teratur dan tertib diasumsikan akan lebih berhasil dari siswa yang tinggal dalam masyarakat yang kacau balau. Lingkungan sekolah yang baik, teratur, fasilitas memadai dan guruguru yang tanggung jawab akan memberi hasil lebih baik dari pada lingkungan yang kurang baik.

Tujuan tersebut dapat terpenuhi bila pengajaran bahasa Inggris di sekolah dapat memadukan empat aspek keterampilan berbahasa yaitu mendengar, berbicara, membaca dan menulis. Pola pengajaran seperti itu dapat terwujud jika berbagai komponen dalam pembelajaran seperti metode, pendekatan, desain, prosedur dan lingkungan kebahasaan kondusif (Kumaravadivelu, 2006:16). Karenanya, sekolah diharapkan mampu menciptakan pengajaran bahasa Inggris secara baik dengan memberdayakan sumber daya dan fasilitas yang dimiliki seoptimal mungkin.

Berangkat dari deskripsi berbagai faktor penunjang dalam pelaksanaan keberhasilan pembelajaran bahasa Inggris di sekolah, peneliti memilih Sekolah 
Menengah Atas Negeri 81 sebagai latar penelitian dengan beberapa alasan.

Pertama, SMAN 81 merupakan sekolah menengah atas yang berhasil dalam pembelajaran bahasa Inggris tingkat sekolah menengah atas di Jakarta. Sesuai dengan kutipan dari Panduan Pendidikan SMAN 81 (2013-2014:59) SMA Negeri 81 secara berturut-turut selama dua tahun terakhir (2011-2013) memperoleh prestasi yang membanggakan meraih peringkat pertama Ujian Nasional di DKI Jakarta, yaitu dengan nilai rata-rata bahasa Inggris $8.50 \quad$ (2011-2012), $8.78 \quad$ (2012-2013) (program IPA), 7.98 (2011-2012), 8.00 (2012-2013) (program IPS). Selain itu juga prosentase lulusan diterima di PTN/PT Luar Negeri empat tahun terakhir (20102013) dengan prosentase $89,92,95,98$ dari hasil prosentasi tersebut terus meningkat dari tiap tahunnya.

Kedua, SMA Negeri 81 meraih prestasi akademi dua tahun terakhir dalam berbagai lomba, namun penulis hanya melaporkan prestasi lomba dalam bidang studi bahasa Inggris. Adapun lomba-lomba yang diraih oleh SMA Negeri 81 yang dikutip dari Panduan Pendidikan (20132014:55) yaitu; pada tahun 2011 meraih peringkat pertama lomba English Debate tingkat Nasional di Kementerian Budaya dan Pariwisata, meraih peringkat pertama International

School

Debating
Championship tingkat Internasional di Skotlandia. Sedangkan pada tahun 2012 meraih peringkat pertama lomba Debat Bahasa Inggris tingkat DKI Jakarta di Universitas Atmajaya, peringkat pertama dalam lomba English Debate tingkat DKI Jakarta di SMAN 70.

Ketiga, selain itu juga, masih dalam Panduan Pendidikan (2013-2014:2) SMAN 81 menerapkan budaya pembelajaran bahasa Inggris yang sangat baik, baik itu budaya memiliki visi dan misi belajar bahasa Inggris yang jelas, budaya kerja keras, serius, dan aktif, budaya disiplin mengikuti pelajaran tambahan, budaya inovatif dalam strategi pembelajaran, budaya guru yang aktif dan proaktif, budaya menghargai waktu, budaya pembumian bahasa Inggris di lingkungan sekolah, budaya menciptakan semangat berkompetensi, budaya mengucapkan salam dalam bahasa Inggris ketika berjumpa dan berpisah, maupun budaya pengembangan diri siswa secara terpadu.

Melalui prestasi yang diperoleh siswa khususnya pada bidang studi bahasa Inggris, maka perlu adanya suatu usaha untuk mengadakan suatu penelitian tentang bagaimana penerapan pembelajaran bahasa Inggris yang dilakukan oleh guru bahasa Inggris di sekolah ini. Agar mendapatkan gambaran proses pembelajaran secara 
holistik, penulis melakukan penelitian dengan menggunakan metode ethnografi.

Berdasarkan uraian di atas, pokok masalah yang dibahas dalam penelitian ini di fokuskan pada proses pembelajaran bahasa Inggris di SMAN 81. Pokok masalah tersebut cukup luas, maka ada beberapa subfokus yang akan di teliti seperti: (1) tujuan pembelajaran bahasa Inggris di SMAN 81; (2) bentuk kurikulum (silabus) bahasa Inggris yang di gunakan; (3) pendekatan, metode, dan teknikyang dimanfaatkan guru dalam pembelajaran bahasa Inggris; (4) sistem penilaian yang digunakan guru dalam pembelajaran bahasa Inggris.

Secara umum penelitian ini bertujuan untuk memperoleh pemahaman yang mendalam bagaimana proses pembelajaran bahasa Inggris yang dilaksanakan di SMA N 81 Jakarta Timur.

\section{METODOLOGI PENELITIAN}

Penelitian ini menggunakan pendekatan kualitatif dengan metodeetnografi karena akan mendeskripsikan karakteristik suatu kelompok atau masyarakat sebagai subjek yang diteliti. Jadi penelitian ini mengkaji perilaku manusia dalam seting alamiah yang dilihat dari perspektif budaya. Spradley berpendapat bahwa etnografi cenderung menggambarkan budaya dan aspek-aspeknya. Kemudian pengetahuan yang diperoleh manusia itu digunakan untuk menginterpretasikan dan menimbulkan perilaku. Perilaku disini menurut (Spradley,1980) adalah perilaku subjek yang diteliti terutama guru dan siswa yang sedang terlibat dalam proses belajar mengajar di dalam kelas.

Dengan penelitian etnografi penulis melakukan studi dengan mencoba menjelaskan proses pembelajaran bahasa Inggris di kelas yang terjadi di SMAN 81 Jakarta Timur. Untuk itu peneliti akan melakukan kegiatan penelitian dengan melakukan observasi, wawancara, serta kajian dokumen. Hal ini sesuai dengan karakteristik penelitian kualitatif, yaitu natural, deskriptif, penekanan proses, induktif, dan penekanan makna. Sifat natural adalah peneliti sebagai instrumen dan sumber data langsung. Bersifat deskriptif karena data yang dikumpulkan akan berupa kata-kata atau gambar. Sifat penekanan proses karena memang lebih menekankan proses daripada hasilnya. Bersifat induktif karena cara menganalisis datanya secara induktif dan tidak termaksud membuktikan sebuah hipotesis. Sifat penekanan makna karena ingin menjelaskan situasi-situasi yang terjadi di dalam seperti melihat perspektif guru ketika menggunakan teknik atau metode mengajar bahasa Inggris di dalam kelas. 
HASIL

\section{Tujuan Pembelajaran Bahasa Inggris}

Tujuan mempelajari bahasa Inggris di SMA Negeri 81 yaitu untuk berkomunikasi secara lisan dan tulis. Berkomunikasi adalah memahami dan mengungkapkan informasi, pikiran, perasaan, dan mengembangkan ilmu pengetahuan, teknologi, dan budaya. Kemampuan berkomunikasi dalam pengertian yang utuh adalah kemampuan berwacana, yakni kemampuan memahami dan/atau menghasilkan teks lisan dan/atau tulis yang direalisasikan dalam empat keterampilan berbahasa, yaitu mendengarkan, berbicara, membaca dan menulis. Keempat keterampilan inilah yang digunakan untuk menanggapi atau menciptakan wacana dalam kehidupan bermasyarakat. Oleh karena itu, mata pelajaran Bahasa Inggris diarahkan untuk mengembangkan keterampilanketerampilan tersebut agar lulusan mampu berkomunikasi dan berwacana dalam bahasa Inggris pada tingkat literasi tertentu.

\section{Silabus Pembelajaran}

Di SMAN 81 Jakarta Timur, silabus dipandang sebagai pedoman mengajar yang berisi materi yang akan diajarkan. Silabus juga merupakan pedoman untuk menyusun skenario pembelajaran danpenilaian. Pandangan tersebut berimplikasi pada unsur-unsur yang terdapat dalam silabus haruslah berisi hal-hal rinci dan operasional mengenai berbagai unsur pembelajaran yang dapat dijadikan pedoman untuk mewujudkan apa yang dimaksud oleh kurikulum kedalam bentuk langkah-langkah untuk mencapai tujuan pembelajaran.

\section{Pendekatan, Metode, dan Tehnik Guru dalam Mengajar}

Dalam proses pembelajaran metode mengajar yang dipakai dipraktikkan oleh guru di SMAN 81 Jakarta adalah metode presentation, discussion, rote-playing simulation, project/takehome assignment, lab work. Dengan menggunakan berbagai macam metode dalam proses pembelajaran, siswa dan guru dapat termotivasi untuk lebih giat dan tidak membosankan dalam proses pembelajaran.Sementara Itu, dalam pengajaran di kelas mereka selalu menggunakan bahasa Inggris sebagai bahasa pengantar.

Berdasarkan pengamatan peneliti, SMA Negeri 81 Jakarta melaksanakan pembelajaran bahasa Inggris dengan menggunakan pendekatan literasi yang bertujuan untuk mempersiapkan siswa untuk terjun ke dalam masyarakat modern. Ini didasarkan atas teori bahasa, teori belajar bahasa, dan tujuan pembelajaran bahasa yang dipedomani oleh informan. 


\section{Sistem Pnilaian}

Temuan mengenai penilaian dalam penelitian pada proses pembelajaran bahasa Inggris di SMAN 81 Jakarta selalu memberikan penilaian terhadap siswa baik pada aspek kognitif, psikomotor, maupun afektif. Khusus untuk penilaian guru-guru di sekolah ini menerapkan penilaian informal berkesinambungan pada tugas/aktifitas di kelas dan pada pekerjaaan rumah (PR), penilaian mandiri dan penilaian bersama (guru dan siswa), serta penilaian produk (penilaian formalities forrnatif).

\section{PEMBAHASAN}

\section{Tujuan Pembelajaran Bahasa Inggris}

Tujuan pembelajaran bahasa Inggris di SMAN 81 secara umum adalah agar siswa dapat mencapai kompetensi komunikatif. Kompetensi tersebut meliputi kemampuan berkomunikasi dalam bahasa Inggris lisan dan tulisan guna membekali siswa untuk mendapatkan ilmu pengetahuan, mempersiapkan siswa melanjutkan sekolah, dan pada akhirnya mempersiapkan siswa untuk terjun ke masyarakat.

Seiring dengan perkembangan teori dari masa ke masa, terbukti bahwa terdapat perbedaan terminology kompetensi (competence) yang di definisikan oleh Chomsky (1965) maupun Hall dan Jones (1976). Chomsky berpendapat bahwa kompetensi merupakan pengetahuan yang dimiliki pengguna bahasa mengenai bahasa tersebut, yang membedakannya dengan ferformansi (performance) yakni aktualisasi bahasa (tindak tutur) dalam konteks sebenarnya. Sedangkan kompetensi menurut Hall dan Jones merupakan kumpulan keterampilan, sikap, dan pengetahuan yang dapat didemonstrasikan oleh siswa yang berasal dari pemahaman secara eksplisit dari hasil pembelajaran yang diharapkan 'Competencies are composite skills, behaviors, or knowledge that can bedemonstrated by the learner and are derived from explicit conceptualizations of the desired outcomes of learning.

Pemahaman terhadap salah satu elemen dasar dalam belajar bahasa khususnya pemahaman aspek-aspek teknis dan kendala kendalanya memang tidak menjamin bahwa sebuah program pengajaran bahasa akan berhasil dengan baik, tetapi dengan memahami aspek-aspek teknis semacam ini, para siswa dan guru diharapkan akan lebih mampu menyempurnakan proses pembelajaran yang akan membawa siswa ketujuan akhir yang diharapkan.

Selanjutnya, Hall dan Jones mengemukakan bahwa kompetensi berada pada suatu hirarki yang secara berurutan diawali dari pencapaian terendah ke yang lebih tinggi, yaitu sasaran (objective), 
subkompetensi

(subcompetency),

kompetensi (competence) dan tujuan (goal).

Ini dapat dijabarkan bahwa competency lebih spesifik dari goal, subcompetency lebih spesifik dari competency, dan objectives lebih spesifik dari subcompetency.

Berdasarkan paparan diatas dapat dikatakan bahwa setidaknya terdapat beberapa hal yang berkaitan dengan kompetensi yaitu kompetensi; 1) berkenaan dengan kemampuan siswa melakukan sesuatu dalam berbagai conteks, 2) menjelaskan bagaimana belajar yang didapat oleh siswa untuk nencapai kemampuan tertentu, 3) merupakan hasil belajar (learning outcome) yang menjelaskan tentang hal-hal yang dilakukan siswa setelah melalui proses pembelajaran, dan 4) kemahiran siswa melakukan sesuatu harus didefinisikan secara jelas dan luas dalam suatu standar yang dapat dicapai melalui kinerja yang dapat diukur.

\section{Silabus Pembelajaran}

Silabus dipandang sebagai pedoman bagi guru dalam melaksanakan kegiatan belajar atau sebagai susunan sebuah mata pelajaran yang akan dipelajari siswa dalam suatu periode tertentu. Pandangan yang berbunyi bahwa silabus merupakan pedoman bagi guru dalam melaksanakan kegiatan belajar menunjukkan bahwa silabus merupakan bagian yang tak terpisahkan dari kurikulum sebagai keseluruhan program sekolah, termasuk didalamnya bahan pelajaran yang harus disampaikan kepada siswa pada level tertentu. Oleh karena itu, silabus harus berisikan keterangan dan penjelasan yang lebih rinci dan operasional mengenai berbagai unsur pembelajaran yang dapat dijadikan sebagai pedoman untuk menerjemahkan dan mewujudkan apa yang terkandung dalam kurikulum kedalam bentuk seperangkat pengajaran khusus sesuai dengan tingkatan siswa.

Pandangan terhadap silabus yang dipedomani guru-guru bahasa Inggris di SMAN 81 sejalan dengan definisi (Dubin dan Olshtain, 1985)yang mengatakan "A syllabus is a more detailed and operational statement teaching and learning elements which translates the philosophy of the urriculum into a series of planned steps leading towards more narrowly defined objectives at each level.

Dari kutipan di atas, silabus dapat dikatakan sebagai pernyataan yang rinci dan operasional tentang unsur-unsur pembelajaran yang menerjemahkan filosofi kurikulum kedalam rangkaian langkah-langkah terencana yang mengarah pada tujuan setiap tingkatan kelas secara lebih sempit dan rinci.

Pandangan kedua yang diyakini guru-guru bahasa Inggris bahwa silabus 
merupakan susunan sebuah mata pelajaran yang akan dipelajari siswa dalam satu periode belajar. Pandangan itu mengisyaratkan pengertian yang lebih sempit dibandingkan dengan pandangan pertama. Dalam hal ini, silabus yang hanya dianggap sebagai susunan materi pelajaran yang harus dipelajari siswa dalam suatu periode tertentu, merupakan bagian kecil dari keseluruhan program sekola yang tercatat dalam kurikulum yang ada. Pengertian seperti itu juga diyakini oleh (Rodgers, 1989) yang mengatakan bahwa silabus itu merupakan materi pelajaran ang harus diberikan kepada siswa pada suatu program pengajaran tertentu.

Pengembangan silabus bahasa Inggris di SMAN 81 bertujuan untuk menyesuaikan bahan pelajaran dengan tujuan pengajaran yaitu; mengaitkan bahan pelajaran bahasa Inggris dengan materi lain, menyesuaikan bahan pelajaran bahasa Inggris dengan berkembangan ilmu pengetahuan. Menyesuaikan bahan pelajaran dengan tujuan pengajaran merupakan tujuan utama dari pengembangan silabus bahasa Inggris di sekolah.

Dari uraian di atas dapat disimpulkan bahwa penyusunan dan pengembangan silabus pembelajaran bahasa Inggris di sekolah ini cukup efektif dilakukan karena ingin mempertimbangkan beberapa hal yang memang sudah tercantum di dalam kurikulum. Selain itu, silabus pembelajaran yang dibuat cukup representatif dan dapat dipergunakan dalam berbagai situasi karena lebih bersifat fleksibel.

\section{Pendekatan, Metode, dan Tehnik Guru dalam Mengajar}

Ketika guru akan mengajarkan bahasa, maka terlebih dahulu guru harus memahami falsafah pengajaran bahasa pada tingkatan teori, prinsip, dan prosedur. Menurut Anthony (dalam Brown,1994), ada tiga bentuk konseptualisasi yang disebut dengan pendekatan (approach), metode (method) dan teknik (technique).

Pendekatan merupakan asumsi korelatif yang berkaitan dengan hakikat, pengajaran dan pembelajaran bahasa. Pendekatan berfungsi untuk mendeskripsikan bagaimana seseorang memperoleh pengetahuan tentang bahasa yang dipelajarinya.

Metode adalah realisasi praktis dari sebuah pendekatan. Dengan demikian metode merupakan rencana keseluruhan dalam penyajian bahan pelajaran dengan menggunakan prosedur tertentu dalam menerapkan jenis aktivitas, peran guru dan pembelajar, materi pelajaran, serta model silabus yang digunakan. Jadi, metode meliputi berbagai prosedur dan teknik. 
Teknik bersifat implementasional. Jadi, teknik merupakan cara atau aktivitas khusus yang diterapkan di dalam kelas yang disesuaikan dengan metode dan pendekatan.

Pada dasarnya terdapat berbagai metode pembelajaran bahasa berdasarkan apa yang diyakini, diobservasi, dipahami dan diinterpretasi oleh guru yang dapat mengembangkan potensi dan membentuk karakter siswa. Namun, sesungguhnya hal tersebut dapat disesuaikan dengan kebutuhan guru dan siswa. Hal ini selaras dengan pendapat (Nunan, 1994) tentang analisis kebutuhan 'Need Analysis' yakni program pembelajaran harus dirancang sesuai dengan kebutuhan siswa dan memiliki tujuan yang telah dirumuskan sebelumnya secara jelas.

Fakta dilapangan menunjukkan bahwa para guru lebih banyak dan dominan menerapkan metode Iangsung, yaitu penggunaan bahasa Inggris sebagai bahasa pengantar ketika memberikan serta menjelaskan materi atau bahan ajar kepada siswa. Selain itu guru bahasa Inggris juga sering menggunakan metode terjemahan tata bahasa. Jadi penggunaan metode ini memang terjadi apabila ada beberapa hal yang memerlukan penjelasan husus. Namun demikian, pemakaian bahasa Inggris sebagai bahasa pengantar sangat efektif karena sangat membantu siswa untuk melihat bagaimana sebenarnya menggunakan bahasa tersebut dalam konteks yang sebenarnya.

\section{Pada pengajaran keterampilan} menyimak, guru dikelas lebih banyak menggunakan metode audiovisual yaitu dengan mendengarkan dialok dari tape recorder atau menyimak dari tayangan LCD yang materinya diakses dari internet yang sudah tersedia di dalam kelas.Untuk kegiatan ini guru sering kali mengajar siswa di laboratorium bahasa dalam mengajarkan keterampilan menyimak. Kegiatan ini mernang sangat diperlukan karena mengingat bahwa keterampilan mendengarkan bunyi-bunyi huruf tertentu, intonasi, penekanan atau jedah, hal ini sangat diperlukan untuk kegiatan pembiasaan mendengarkan pengucapan ujaran dari penutur asing yang sebenarnya.

Pada pengajaran keterampilan membaca, guru paling sering menggunakan teknik skimming dan scanning yang menekankan pada pembaca untuk mendapatkan pemahaman teks serta untuk mendapatkan informasi khusus atau tertentu. Selama pengamatan peneliti, penerapan teknik skimming and scanning cukup efektif untuk menuntun siswa dalam menguasai teknik memahami sebuah peragraf singkat, yang akhirnya berkembang menjadi pemahaman sebuah wacana yang terdiri dari beberapa 
paragraph. Hanya saja teknik skimming ini kurang begitu efektif ketika teks bacaan yang diberikan mengandung kalimatkalimat yang cukup kompleks dengan penggunaan kosa kata yang agak sulit.

Pada pengajaran keterampilan berbicara, guru selalu melibatkan semua siswa untuk aktif menggunakan bahasa Inggris secara lisan melalui berbagai jenis kegiatan seperti tanya jawab antara guru dan siswa, antara siswa dan siswa, kegiatan diskusi kelompok, kegiatan dialok, monolog atau percakapan. Peneliti berpendapat bahwa kegiatan seperti ini memang sebaiknya tetap bervariasi agar para siswa terdorong untuk tetap mau menggunakan bahasa sasaran sebagai bahasa komunikasi antar peserta diskusi.

Pada pengajaran menulis, kegiatan pembelajaran ditekankan pada keterampilan menulis kalimat, paragraph, wacana, serta karangan bebas yang dilakukan dengan metode penugasan langsung seperti pekerjaan yang berbasis proyek/take home assignment. Model atau pendekatan pembelajaran yang relative baru, yang menekankan belajar secara kontekstual melalui kegiatan-kegiatan yang kompleks. Fokus pembelajaran terletak pada konsep-konsep dan prinsipprinsip inti dari suatu disiplin ilmu, melibatkan siswa dalam pemecahan masalah dan kegiatan atau tugas bermakna, memberi kesempatan siswa bekerja secara otonom dan mengkonstruk pengetahuan mereka sendiri, serta mencapai puncaknya menghasilkan produk yang nyata.

Dalam hal ini (Larsen dan Freeman, 2000) berpendapat bahwa guru yang menggunakan metode Iangsung menginginkan para siswa agar mereka mampu berkomunikasi menggunakan bahasa sasaran yang sedang dipelajari. Oleh karena itulah, siswa hendaknya bisa berpikir menggunakan bahasa asing yang sedang mereka tekuni.

Dari uraian di atas dapat disimpulkan bahwa metode dan teknik guru bahasa inggris di kelas dalam kegiatan belajar mengajar keterampilan berbahasa sangatlah bervariasi sesuai dengan keadaan siswa serta materi ajarnya. Semua metode dan teknik yang digunakan bertujuan untuk membantu siswa agar mampu menguasai keempat keterampilan bahasa tersebut secara aktif.

\section{Sistem Penilaian}

Penilaian merupakan bagian integral dari proses pembelajaran. Oleh karena itu, teknik dan instrumen penilaian direncanakan bersama-sama dengan penyusunan silabus. (Linn dan Gronlund, 1995) mendefinisikan penilaian (assessment) sebagai suatu cara untuk mendapatkan informasi tentang kinerja siswa dan dilakukan 
bukan hanya dengan tes tertulis tapi juga dengan tampilan tugas otentik.

Dalam pembelajaran, guru melakukan penilaian bersamaan dengan proses pembelajaran atau disebut dengan on going assessment. Penilaian yang dilakukan bersifat otentik, artinya menilai apa yang diperoleh siswa saat proses pembelajaran bahasa Inggris berlangsung. Teknik penilaian yang digunakan direncanakan dan disusun sesuai dengan tujuan belajar saat itu. Hasil penilaian digunakan baik oleh guru maupun siswa sebagai bahan refleksi. Guru dapat mengetahui tingkat efektivitas pembelajaran yang diselenggarakan dari penampilan siswa. Siswapun dapat mengetahui tingkat penguasaan kompetensi yang harus dikuasainya dari nilai yang dia dapatkan.

Agar hasil penilaian betul-betul obyektif dan transparan, guru melaksanakan penilaian melalui beberapa tahapan. Sebelum penilaian, guru akan menjelaskan tentang rubrik atau kriteria penilaian kepada siswa, kemudian guru mempersiapkan format penilaiannya.

Hal ini dimaksudkan agar siswa mengetahui apa yang harus dicapai dan usaha apa yang harus dilakukan untuk mendapatkan nilai yang baik.
Setelah pelaksanaan suatu penilaian, guru mengajak siswa untuk melakukan refleksi terhadap hasil yang dicapai masing-masing siswa. Penilaian dilakukan dengan menggunakan berbagai cara yang dilakukan SMAN 81 Jakarta yang disebut dengan (tes tertulis), performance (penampilan), product (produk), portfolio (portofolio), dan project.

Pada indikator dalam silabus, target kompetensi wacana yang diharapkan dicapai siswa meliputi (1) kompetensi tindak bahasa (actional competence) yaitu menyimak (listening), berbicara (speaking), membaca (reading), dan menulis (writing). Kompetensi tindak bahasa ini dalam bahasa lisan disebut dengan tindak tutur (speech act) dan dalam bahasa tulis disebut retorika (rethoric); (2) kompetensi pembentuk wacana (discourse markers) yang mengacu pada kemampuan menerapkan unsur-unsur piranti kohesi, koherensi, konteks situasi, struktur genre, dan struktur percakapan; (3) kompetensi kebahasaan (linguistic competence) mengacu pada kemampuan menerapkan dan memahami unsur-unsur tata bahasa, kosa kata, lafal, dan ejaan yang benar; (4) kompetensi sosiokultural (sociocultural competence) mengacu pada kemampuan 
menyatakan pesan dengan benar dan berterima menurut konteks sosial budaya yang terkait; (5) kompetensi strategis (strategic competence) yang mengacu pada kemampuan dan keterampilan menerapkan berbagai strategi berkomunikasi; (6) sikap (attitude) mengacu pada rasa percaya diri dan keinginan siswa untuk meningkatkan keterampilan berbahasa dengan berbagai cara dan strategi belajar. Dalam proses pelaksanaan penilaian di dalam kelas, keenam kompetensi pembentuk kompetensi wacana yang disebutkan di atas tercermin dalam empat keterampilan bahasa yang meliputi listening, speaking, reading dan writing.

Dalam menilai berbicara (speaking), unsur-unsur yang dinilai guru adalah kelancaran (fluency), ketepatan pemakaian bahasa (accuracy), kosa kata, argumentasi, ekspresi, dan sikap (attitude). Nilai sikapditujukan pada sikap siswa ketika tampil berbicara dan sikap ketika mendengarkan siswa lain berbicara.

Dalam penilaian speaking, apabila siswa melakukan kesalahan baik tata bahasa maupun lafal, guru tidak langsung memberikan koreksi. Hal ini dilakukan dengan pertimbangan agar siswa tidak minder dan tetap percaya diri untuk dapat menyelesaikan percakapannya hingga selesai. Biasanya, guru melakukan perbaikan pada akhir kegiatan dan ditujukan kepada seluruh siswa.

Penilaian menyimak (listening) dilakukan dengan tes tertulis dengan menggunakan rekaman kaset atau suara guru, dapat pula dengan merespon perintah lisan guru. Rubrik penilaian berupa kriteria nilai excelent bila siswa mengerti perintah guru dan langsung melakukannya dengan benar, nilai good bila siswa memahami perintah guru tapi masih berfikir dulu sebelum melakukan tapi kegiatannya benar dan seterusnya. Dalam merespon rekaman dari kaset atau suara guru, siswa dapat menjawab pertanyaan tentang informasi spesifik, informasi umum, dan informasi rinci.

Penilaian berbicara (speaking) dilaksanakan antara lain dengan teknik role play. Secara berpasangan siswa diberi peran tertentu untuk melakukan dialog yang bermakna. Guru dapat pula menggunakan teknik wawancara seraya menggunakan media yang sesuai seperti gambar atau realita. Siswa dapat pula diminta untuk bermonolog di depan teman-temannya. Untuk menilai keterampilan berbicara guru menggunakan sistem penskoran berjenjang dengan skala 0-5 terhadap aspek-aspek kelancaran (fluency), ketepatan tata bahasa (grammar), penguasaan kosa kata (vocabulary), 
ketepatan ucapan (pronunciation), dan kemampuan berkomunikasi.

Penilaian membaca (reading) dibagi menjadi dua yaitu membaca dalam hati (reading silently) dan membaca nyaring (reading aloud). Dalam reading silently, tugas siswa antara lain dapat menemukan informasi spesifik, informasi umum, informasi rinci, atau langkah-langkah retorika dari teks yang mereka baca. Ketika membaca nyaring (reading aloud), unsur-unsur yang dinilai guru adalah intonasi (intonation), pronunciation (pengucapan), dan sikap (attitude). Penilaian reading silently berupa tes tertulis, sementara reading aloud berupa performance. Nilai keterampilan reading adalah rata-rata nilai reading silently dan reading aloud.

Untuk menilai keterampilan menulis (writing), guru menilai isi (content), apakah isinya sesuai dengan tugas yang diberikan dan jugs kesinambungan dari setiap kalimat. Unsur kedua yang dinilai adalah organisasi tulisan (organization) terutama berkaitan dengan genre yang digunakan, dan yang ketiga adalah bahasa (language) yang berkaitan dengan variasi pemilihan kosa kata dan pola kalimat. Sikap dalam menulis adalah unsur keempat yang dinilai. Sikap di sini mencakup mekanik yang meliputi penggunaan huruf besar kecil, ejaan, tanda baca, dan kerapian tulisan secara keseluruhan. Jenis penilaian writing biasanya adalah penilaian produk.

Di SMAN 81 jakarta, guru mengupayakan agar dalam satu tahun pelajaran siswa mengalami kelima jenis penilaian sesuai dengan tuntutan kurikulum. Nilai performance didapat siswa pada penilaian speaking, listening dan reading aloud. Nilai product dilihat dari hasil karya pada penilaian writing. Nilai portfolio diterapkan dengan meminta siswa mengumpulkan seluruh hasil karya yang sudah dinilai dalam sebuah map dan dikumpulkan pada akhir semester. Tes tertulis (paper and pencil test) didapat dari penilaian listening dan reading silently. Penilaian berbasis project menuntut siswa untuk mencari berbagai sumber agar memiliki pengetahuan yang cukup banyak untuk dapat menyajikan suatu project. Karena itu biasanya penilaian berbasis project hanya dilakukan satu kali dalam satu semester.

Produk atau hasil karya siswa akan dinilai dan diberi catatan oleh guru. Kemudian dibagikan pada siswa untuk diperlihatkan dan diparaf oleh orang tua. Produk yang telah dinilai dan diparaf orang tua kemudian dipajang di dinding 
kelas. Pemajangan hasil karya ini dimaksudkan agar siswa bangga akan hasil karyanya dan mau bersikap terbuka menerima kritik dan masukan dari berbagai pihak (guru dan temantemannya).

Selain penilaian otentik yang terintegrasi dengan kegiatan pembelajaran, ada pula ulangan blok yang diselenggarakan pada akhir semester. Di SMAN 81 Jakarta, ulangan blok untuk mata pelajaran bahasa Inggris dilaksanakan dengan menguji keempat keterampilan yang diajarkan. Listening dilaksanakan dengan media kaset dan tape recorder, reading dengan paper and pen test dan performance, writing dengan produk dan speaking dengan melakukan dialog dengan guru satu persatu. Dengan demikian waktu yang diperlukan bisa mencapai enam jam pelajaran atau Iebih.

Untuk pelaporan hasil penilaian, di samping sebagai kewajiban administratif dan dilaporkan pada Kepala Sekolah, guru harus melaporkan hasil penilaian kepada orang tua minimal dua bulan sekali dalam bentuk Lembar Kemajuan Belajar Siswa. Pelaporan ini berdampak positif bagi orang tua, siswa, maupun guru. Orang tua dapat memonitor kemajuan belajar putra/putrinya sejak awal sehingga dapat memberikan dorongan dan perhatian pada siswa. Bagi guru, sistem pelaporan ini memaksa guru untuk tertib administrasi dan tidak malas. Dalam merencanakan dan melaksanakan penilaian, guru nampak telah menerapkan prinsip-prinsip penilaian seperti yang dikemukakan oleh (Linn dan Gronlund).

Membuat 'deal' dengan siswa sebelum pelaksanaan penilaian termasuk penerapan prinsip pertama yaitu kejelasan tentang apa yang akan dinilai. Penerapan prinsip kedua tentang prosedur telah disesuaikan dengan karakteristik keterampilan yang akan dinilai. Prinsip ketiga telah dilaksanakan dengan digunakannya prosedur penilaian yang beragam, serta mempertimbangkan keterbatasan setiap jenis penilaian sebagai penerapan prinsip keempat. Penerapan prinsip kelima tampak pada digunakannya hasil penilaian sebagai bahan refleksi bukan saja bagi siswa tapi juga bagi guru dan orang tua.

Melaksanakan penilaian untuk keempat aspek keterampilan berbahasa (listening, speaking, reading, writing) pada setiap jenis teks tidaklah mudah. Jumlah siswa perkelas yang besar, rubrik penilaian yang rinci, dan alokasi waktu yang terbatas, membuat guru harus benar-benar terampil dan menyediakan waktu tambahan. Waktu tambahan dibutuhkan untuk memberikan kesempatan berlatih dan memberi koresksi atau feedback pada setiap siswa sebelum mereka dinilai, misalnya latihan 
untuk monolog/dialog dan mengoreksi konsep tulisan siswa.

\section{Kesimpulan}

Secara khusus proses pembelajaran yang di laksanakan di SMAN 81 cukup berhasil, ini dapat dilihat dari beberapa indikasi sebagai berikut:

Pertama tujuan pembelajaran bahasa Inggris diarahkan pada penguasaan kompetensi komunikatif kebahasaan, strategis, sosiokultural, aksional dan kompetensi wacana. Prinsip-prinsip pembelajaran bahasa dengan pendekatan literasi melibatkan interpretasi, kolaborasi, konvensi, pengetahuan budaya, pemecahan masalah

Kedua silabus bahasa Inggris yang dikembangkan di SMAN 81 adalah silabus fokus variabel atau disebut juga silabus proporsional. Silabus ini memberikan penekanan yang seimbang kepada struktur bahasa, fungsi bahasa, dan proses atau pengalaman memperoleh bahasa. Tahapan pengembangan silabus yang dilakukan adalah memahami kurikulum, membuat pemetaan, menyusun program tahunan dan program semester, menyususn silabus pembelajaran, menyususn kisi-kisi penilaian, dan membuat rencana pelaksanaan pembelajaran. Silabus dikembangkan dengan cermat dan kreatif oleh guru dengan mempertimbangkan karakteristik siswa, waktu yang tersedia, serta situasi dan kondisi lingkungan. Dengan adanya silabus guru dapat melaksanakan tugasnya lebih sistematis.

Ketiga pendekatan, metode dan teknik yang dimanfaatkan guru dalam proses pembelajaran di kelas. Dalam pembelajaran bahasa lnggris pendekatan metode dan teknik merupakan salah satu unsur yang menentukan desain kegiatan belajar yang dikembangkan guru dalam mengajar mata pelajaran bahasa lnggris sudah tepat, karenamempertimbangkan kemampuan siswa serta jenis kompetensi berbahasa yang diajarkan. Secara umum pendekatan mengacu pada asumsi-asumsi mengenai hakikat bahasa bagaimana pembelajaran bahasa dilakukan. Pembelajaran bahasa lnggris yang diterapkan guru di kelas yaitu mengembangkan kemampuan berbahasa Inggris siswa yang dipadukan antara pembelajaran bahasa fungsional dan interaksional untuk menghasilkan bentuk pembelajaran bahasa lnggris yang Iebih menyentuh kebutuhan berbahasa siswa. Berdasarkan temuan tersebut perludiintegrasikan sedemikian rupa sehingga menghasilkan kegiatan belajar yang menekankan pada aspek bagaimana bahasa lnggris digunakan sebagai alat komunikasi. 
Keempat penilaian hasil belajar bahasa Inggris di SMAN 81 dilaksanakan bersamaan dengan proses pembelajaran dan bersifat otentik. Penilaian dapat berupa tes dan non tes. Teknik penilaian yang digunakan antara lain, tes tertulis, tes penampilan, portofolio, produk, atau proyek. Hasil penilaian yang dilaporkan berupa nilai menyimak (listening), berbicara (speaking), membaca (reading), menulis (writing), dan sikap. Hasil penilaian diinterpretasikan berdasarkan acuan kriteria dan secara langsung digunakan sebagai bahan refleksi oleh guru dan siswa. Pelaksanaan penilaian yang dilaksanakan secara sistematis mengarah pada penguasaan kompetensi komunikatif sebagai life skill. Di lapangan, pelaksanaan otentik pada ke empat keterampilan berbahasa seperti disebutkan di atas mengalami kendala pada terbatasnya alokasi waktu. Alokasi waktu yang tersedia untuk mata pelajaran bahasa Inggris di SMA hanya empat kali empat puluh lima menit per minggu. Melaksanakan pembelajaran bahasa Inggris membutuhkan alokasi waktu yang lebih banyak. Hal ini berkaitan dengan tiga faktor yaitu: (1) banyaknya materi yang harus dikuasai siswa; (2) pelaksanaan sistem penilaian otentik untuk aspek mendengarkan, berbicara, membaca, dan menulis pada kelas besar; dan kewajiban untuk memberikan pelayanan individual personal kepada siswa.

Secara umum dapat disimpulkan bahwa pada dasarnya terdapat banyak fakor yang menjadi pendukung dan juga sekaligus penghambat proses pembelajaran siswa. Kinerja guru yang profesional, dukungan warga sekolah termasuk kepala sekolah dan staf tata usaha yang maksimal, serta kontribusi orangtua dan masyarakat yang tinggi sangat berpengaruh terhadap hasil belajar siswa.

\section{DAFTAR PUSTAKA}

Brown, H. Douglas. Teaching by Principles. Englewoods Cliffs : Prentice Hall, 1994.

Teaching by Principles, An Interactive Approach to Language Pedagogy. Engleewoods Cliffs: Prentice Hall, 1994.

C. Richards, and Theodore S Rodgers. Approach and Methods in Language Teaching. London: Cambridge University Press, 1992.

Farkhan, Muhammad. The Implementation of Communicative Language Teaching, 2004.

Hall, Gene E. dan Howard L. Jones, Comhetency-Based Education: $A$ process for the Imhrovement of Education. New Jersey: Prentice Hall, Inc., 1976.

Harmer, Jeremy.The Practice of English Language Teaching. London: Longman Grouh Limited 1986. 
Kern, Richard. Literacy and Language Teaching. Oxford: Oxford University Press, 2000.

Kumaradivelu, B., Understanding Language Teaching: from Method to Postmethod. New Jersey: Lawrence Erlbaum, 2006

Larsen, Diane and Freeman, Techniques and Principles in Language Teaching. New York: Oxford University Press, 2000.

Linn, Robert L dan Norman E. Gronlund. Measurement and Assessment in Teaching. New Jersey: Englewood Cliffs, 1995.

, Measurement and Assessment in Teaching, $\quad 7^{\text {th }}$ ed. Englewood Cliffs : Prentice Hall, 1995.

Nunan, DavidTheLeamer-Centerd Curriculum. UK: Cambridge 1994.
SMAN 81. Panduan Pendidikan, Tahun Pelajaran 2013-2014

Spradley, James H. Participant Observation. USA: Polt, Rinehart and Winston, 1980.

Participant Observation. New York: Polt, Rinehart and Winston. 1980.

Tomlinson, Brian. "Introduction" Materials Development in Language Teaching. Cambridge:Cambridge Utiiversity Press, 1998.

Material Development in Language Teaching. Brian Tomlinson (ed), Cambridge: CUP, 1998. 